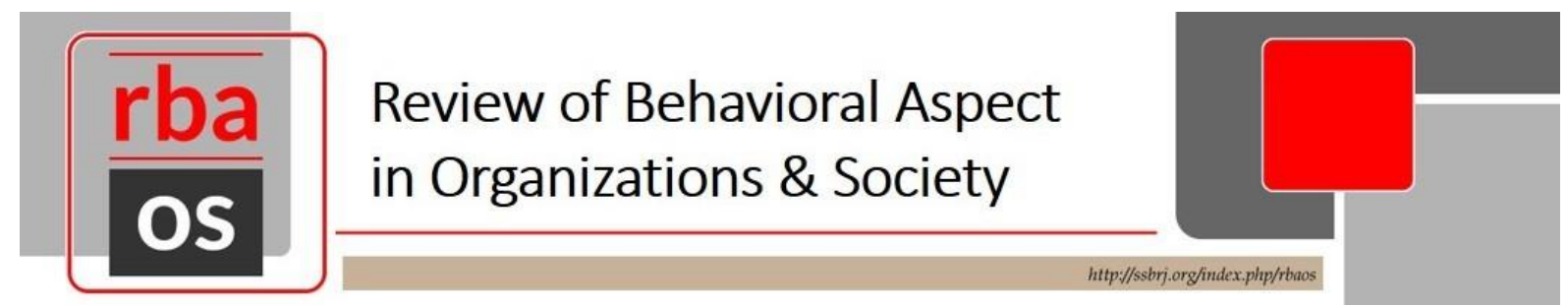

\title{
PUBLIC POLICY IMPLICATION OF SAND MINING SECTOR DYNAMICS IN INDONESIA
}

\author{
Silvi Asna Prestianawati, Brawijaya University, Indonesia \\ Wildan Syafitri, Brawijaya University, Indonesia \\ Suryaning Bawono, Jember University, Indonesia
}

\begin{abstract}
The aim of this paper is to reveal the dynamics of public policy implication of sand mining in Lumajang Regency. Public policy become a key point of investment movement. Qualitative with phenomenology approach is used. The finding of this paper is the system of SKAB becomes a problem source of sand tax leak take. Letting the column of the tonnage/volume of sand released blank became a strategy for miners to minimize the taxes they must submit to the BPRD, whereas it was the basis for taxation. Duplication of SKAB was what the authors believed as the main cause of a substantial sand tax leak where the taxpayers who were authorized by the BPRD should be able to be responsible for the SKAB. This research could be basic consideration for government to make sand mining public policy correction in order to improve regional original income (PAD).
\end{abstract}

Keywords: public policy, sand mining 


\section{Background}

Indonesia with its geographical conditions has the potential to have a variety of natural resources that can be exploited. Agriculture, plantations, livestock, fisheries and even mining are well-available in Indonesia. Mining is one of the abundant natural potentials in Indonesia, including Lumajang Regency, East Java, as one of regions that have the largest sand mining potentials in Indonesia. Lumajang Regency has around 60,000 hectares of sand mining areas spread in various regions. The quality of sand produced is also referred to as the number one quality in Indonesia. Besides building sand, Lumajang also has iron sand containing iron $(\mathrm{Fe})$ ranging from $40 \%$ to $60 \%$. The abundance of sand comes from volcanology of Mount Semeru (the highest mountain in Java) which contains soil or other soil materials which is very low, which is only 3\%. The volume of sand produced by Mount Semeru reaches 1,000,000 cubic hectares annually. Suppose that one cubic meter is valued at IDR 150,000, the real potential that Lumajang Regency can get is around IDR 150 billion per year. Lumajang sand can be used for all development needs at the national level such as concrete manufacturing, toll roads, buildings and so on. This sand must be mined since in addition to being economically profitable, it can also prevent major floods when the rainy season comes.

However, behind the abundant natural resources, there are also problems that never end and are experienced by all regions that have this potential, namely, among others, land acquisition conflicts, crimes, illegal businesses, even social and material corruptions. Land acquisition conflicts usually occur between traditional and modern investors, while crimes mostly occur due to land acquisition conflicts which result in murder, social chaos, even dangerous underground politics (Boni et al., 2015). Illegal businesses also occur due to the high potential of the resources, but the existing licensing process is considered expensive and takes a very long time. So that many investors decide to run their businesses without legal permits (Datt, 2016). The last problem that never ends is corruption, including social and material corruptions. Social corruption is caused by damage to the nature and public facilities caused by investors' business activities.

These problems are closely related to the legal system that is applied, especially in Lumajang. There are still many illegal miners operating in the Lumajang mine area. Around 54 mining points are still illegal, while only 21 mining areas are licensed or legal. These illegal miners enjoy a lot of results or profits that are not gained by legal miners, where they (illegal miners) do not have to pay taxes, licensing fees, reclamation fees and retribution. In fact, they sell sand per cubic cheaper than the price set by legal miners, which is IDR 400,000 per cubic, whereas legal miners sell sand for IDR 600,000 per cubic (Aini, 2015). So, indirectly, legal miners are competing hard with illegal miners.

Seeing the potential of the large sand mining in Lumajang, it can be seen clearly that the income of Lumajang Regency for the exploitation of the sand must be large. However, in reality, the Regional Original Income (PAD) from the process of exploiting the sand is not as imagined. In 2017, Lumajang Regency only received IDR 7 billion, in 2016 was about 6.6 billion, and even in 2014 it only reached IDR 75 million (Dyan, 2018). This indicates an error in mining management so that the Regency has not been able to maximize the results of sand mining exploitation which should be used for more productive things. This condition is not in balance compared to what is suffered by Lumajang Regency, including in terms of the welfare of the Lumajang community. Public roads that are damaged due to the large number of trucks and heavy transportations that go in and out, floods and overflowing rivers, and ecosystem imbalances are the biggest losses resulting in a decline in the welfare of the community around the mining areas. 
This phenomenon is a result of the mismanagement of public policy made by the Government of Lumajang Regency. The authors considered it important to review the public policies that have been made by the Government of Lumajang Regency in relation to maximizing the PAD from sand mining and improving community welfare, to be used as a reference to reorganize the public policy arrangements that have been made regarding sand mining.

\section{Literature Review}

Sand mining is an example of reciprocal externalities that affect groundwater extraction (Chandrakanth, 2015). Demand for sand has increased in recent years because it is very necessary to use it in civil construction, due to the push for urbanization (displacement of people from rural areas) and increasing demand for housing. To fulfill the demand, sand is mined illegally (Baker \& Gadgil, 2017). Demand for sand has encouraged truck owners and contractors to look for quality sand deposits in various rivers. Sand in the river/water flow is allowed to be extracted to a maximum depth of 3 feet from the surface to allow the recharge of groundwater. If the extraction of sand exceeds the 3 feet depth limit, it will affect groundwater recharge. This excessive sand cover inhibits the river's ability to hold and transmit groundwater to open wells and borewell on both sides of the river (Inkenbrandt, et, al, 2014). Demand for sand is a function of the price of sand. Throughout riparian areas, sand serves as a medium for refilling groundwater. Sand from time to time accumulates in layers along river paths along the natural flow of surface water (rivers) and serves to maintain riparian areas so that groundwater can be replenished from rainwater. Sand also functions as a guardian of river ecosystems (Ramkumar et al., 2015). Externalities due to sand mining in groundwater irrigation are expected to reduce groundwater debits if carried out excessively. One of the externalities of sand mining is the decrease in debit of groundwater which has an impact on agricultural irrigation (Benoit \& Comeau, 2015).

The controversy in sand mining cannot be separated from the motives of interest groups working behind the scenes rooted in the booming construction industry today (Nordin, et, al, 2013). Rapid economic growth and explosion-driven job creation are welcomed, but clearly, they have come at a hefty cost of the negative externalities imposed on the environment due to careless sand mining (Farahani \& Bayazidi, 2018). Regardless of the problem of illegal sand mining, the reason behind the practice of careless sand mining is the allocation of river plots through short-term leasing. Short-term leasing (land rent), which provides little incentive for sustainable management, encourages careless mining, give a little time for the trough to be refilled again (Knopp, 2012). The government needs to impose quotas and other restrictions to overcome this problem, but the regulations for the regulation of the sustainability of sand mining need to have a real effect on improving the ecology of the river. A more practical solution to the problem of sand mining lies in empowering local residents, who have a longterm interest in preserving the ecology of the riverbed, and thus are more likely to be involved in sustainable sand management (Ramachandra, et, al, 2018). Since interest groups involved in sand mining and counter-productive policy decisions from state institutions such as the green court, do not guarantee that the situation will change for the foreseeable future. Corruption and abuse of power are the trigger factors for counter-productive policies and betrayal of people's trust in managing nature (Wood, 2014). The issue of lung health due to sand mining is one of the negative issues of sand mining activities (Candeias, et al., 2018; Taylor, 2016).

\section{Research Method}

Qualitative research was chosen to uncover and understand something behind the phenomenon that was still very little known and try to detail completely about research that is difficult to 
reveal by quantitative methods. In addition, qualitative research can also be interpreted as a method that seeks to understand more deeply a phenomenon about something related to research subjects that are reflected in behavior, perception, motivation and action (Moleong, 2011: 6).

\section{Findings}

Dynamics of Sand Mine Problems in Lumajang Regency

Mount Semeru is surrounded by four regencies, namely in the west by Malang Regency, northwest by Pasuruan Regency, north by Probolinggo Regency, and east by Lumajang Regency. The region called Lumajang Regency does indeed seem destined to be related to the blessings of the largest mountain in Java which always experiences varying eruptions with cold lava vomiting both in large and small volumes. Its area has the quality of non-metallic minerals and rocks or abundant rock and non-metallic minerals. The abundance of natural resources does not immediately make Lumajang Regency enjoy the results well. There are even many problems that occur in the field, such as illegal mining.

Illegal mining, according to Hidayat (2018), is a mining activity without any permission at all, or with permission but is not valid. Illegal mining also means mining with legal permits but not according to their coordinates, or miners whose licenses are issued in other owners' mining areas without release. Illegal mining can also be interpreted as licensed miners who carry out mining in the forest area without written recommendations from the Minister of Forestry. The years 2012-2013 are the years when rampant illegal mining took place which caused trucks to go back and forth from Lumajang every day. The large number of trucks loaded outside of tonnage then caused a lot of infrastructure to be destroyed such as roads along the $20 \mathrm{~km}$ Pasirian-Lumajang route. Because of the many uncontrolled illegal mining despite the formation of a special committee to handle illegal mining by the Regional Representative Council of Lumajang Regency, in 2014 there was a rejection of sand mining and even the expulsion of heavy equipment in the community of Selok Awar-Awar mining area.

In addition to the problem of illegal mining and the lack of strict government regulations of Lumajang Regency on mining activities, in 2006 there was an initial problem that contributed to the fluctuation of the Regional Original Revenue from the tax on sand. On October 14, 2004, the Government of Lumajang Regency made two Operational Cooperation Agreements (KSOs) namely KSO No. 8 of 2004 and KSO No. 10 of 2004 concerning tax collection and management of non-metallic minerals and rocks in Lumajang Regency with CV Mutiara Halim and the exploitation of non-metallic minerals and rocks in the ex-land of the Semeru mining regional company of Lumajang Regency, respectively. Then in addition to completing the two KSOs, the Government of Lumajang Regency with PT Mutiara Halim on November 11, 2004 made an addendum on KSO No. 10/2004 which stated among others that Lumajang Regency Government assigned PT Mutiara Halim to collect sales of non-metallic minerals and rocks throughout Lumajang Regency. This KSO contained the assignment to PT Mutiara Halim to carry out the collection of exploitation of non-metallic minerals and rocks in Lumajang Regency with a sand weighing system. In this stage, many oblique responses were directed towards the KSO.

Law No. 18 of 1997 concerning regional taxes and retributions article 6 stated "tax collection cannot be in bulk payment manner (cannot be cooperated with third parties)". Therefore, the Regent at that time revised and reviewed the KSO. The result of the revision and review, which was later called KSO No. 16 of 2005, stated that PT Mutiara Halim must submit the results of the collection of exploitation of non-metallic minerals and rocks in the amount of IDR 
$1,150,000,000$ in 2006 and changes in payments of 5\% annually and adjustments to changes in prices determined by the Regent's decision. So that, in 2006, the Operational Cooperation Agreement (KSO) No. 16 effectively took effect between Lumajang Regency Government and PT Mutiara Halim until 2024. However, even after reviewed, there were still many who saw that the KSO was defective due to the "bulk payment" which was stated based on rupiah instead of percentage of the results obtained by PT Mutiara Halim. This is what was believed to be detrimental to Lumajang Regency.

On December 19, 2008, the Lumajang Regent sent a Letter of the Regent of Lumajang Number 180/1317/427.1/2008 concerning the revocation of the KSO No. 16 of 2005. Seeing the unilateral cancellation, PT. Halim Halim filed a lawsuit at the Surabaya State Administrative Court in which then PT Mutiara Halim was declared victorious, so that the sand management with a weighing system was continued to be carried out by PT Mutiara Halim as KSO number 16 of 2005. The following is a description of the dynamics of the realization of tax on nonmetallic minerals and rocks from 1998-2017.

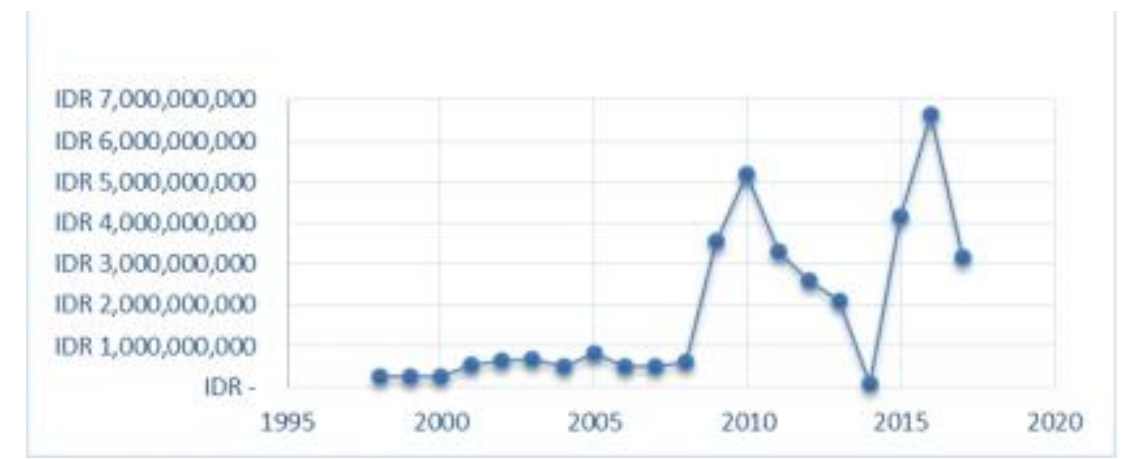

Source : Data processed (2018)

Figure 1. Realization of tax on non-metallic minerals and rocks from 1998-2017

Tax realization from 1998 to 2000 was very minimal, meaning there was almost no significant improvement. Tax collection these years was carried out by the Semeru mining regional company. The absence of tax collection system or model caused almost no significant increasing. It could also be interpreted that in these years the Government of Lumajang Regency had not been able to realize the sand tax properly. But from 2001 to 2008, there was very little increase in the realization of tax revenues. This was due to the existence of a direct collection system to taxpayers, portal systems and the compulsory collection (WAPU) system (partners).

Through the use of these three systems (direct collection system to taxpayers, portal systems and the compulsory collection (WAPU) system), it turned out that the Government of Lumajang Regency still had not been able to raise the realization rate of sand tax even though the KSO whose the purpose was to increase the sand tax, was carried out. But the fact that happened was that the increase in sand tax actually happened significantly in 2009 where the tax collection using portal system was carried out by the Regional Financial Management Service (DPKD) officers and the compulsory collection (WAPU) system on the implementation of development project activities based on Regent Regulations No. 60 of 2008 concerning the operational guidelines of Regional Regulation No. 16 of 2006 and the Decree of the Regent of Lumajang No. 188.45.344/427.12/2008 concerning the stipulation of the Selling Value of Retrieval Results (NJHP) and market or standard prices of non-metallic minerals and rocks. The tax realization continued to increase from 2009 to 2017. 
In 2011, Regional Regulation no. 4 of 2011 was implemented as the basis for collecting nonmetallic mineral and rock taxes imposed on individuals or entities that can collect non-metallic mineral and rock materials using the Self-Assistance collection system with the control card as a function of controlling the volume or tonnage of extracting mining materials as taxation as the basis for imposing taxes to calculate the amount of tax. Dropped very significantly in 2014 due to careless illegal sand mining accompanied by conflicts over mining land which increasingly made the condition of sand mining in Lumajang face a chaotic condition, the sand tax trend in the Regency was able to increase again in 2015 to 2017.

Self-assessment with the control card that functions as a volume control had been able to raise the realization of sand tax as much as 10 to 12 times higher than it of 1999-2009. However, after a field evaluation, it turned out that the last tax realization in 2017 was far from the potential tax. This potential tax meant that actually Lumajang Regency should able to collect sand taxes of IDR 31,094,784,999,625 (assuming that the number of working days was 250 days). On this basis, Lumajang Regency actually experienced a tax leak of IDR $31,091,636,292,475$. According to the field results, it was estimated that this leak was caused by fraud in the use of the Certificate of Origin of Goods (SKAB) issued by the Regional Tax and Retribution Agency (BPRD) to licensed miners. The SKAB contained information about the driver's name, date and time of delivery, destination of shipment, name of Mining License (IUP) holder, serial number, commodity name, vehicle police number, type of vehicle, and volume/tonnage. It was then used as the basis for payment of taxes as seen from the volume/tonnage of sand released. It was given at portals set by the Government of Lumajang Regency by miners and representatives of the BPRD.

This tax collection model was a model that should be measurable and maximize taxes, but what happened in the field was that there were still many deviant activities carried out by miners. For example, the amount of sand tonnage/volume was not filled and the duplication of SKAB was not standardized. This duplication of SKAB was often carried out by sand transporters heading to the stockpiles.

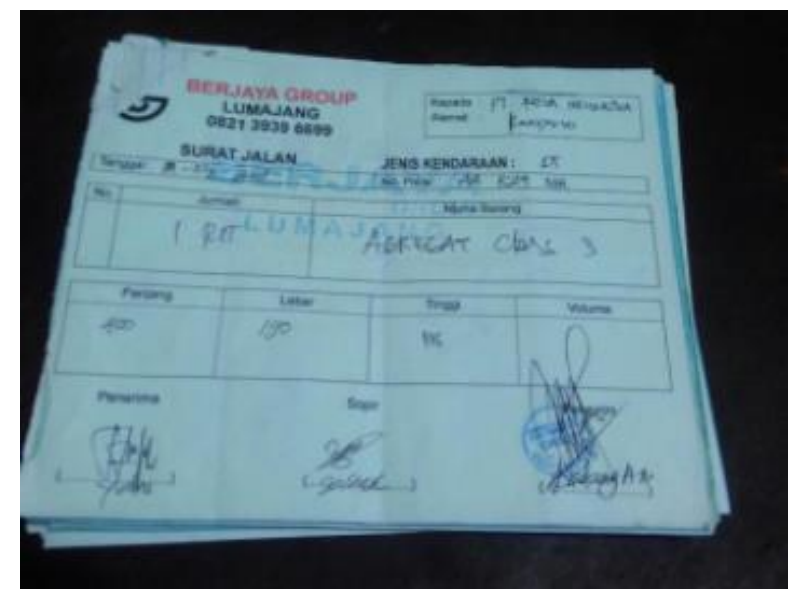

Source: Field survey data (2018)

Figure 2. Letting the sand volume data column blank

Based on field observations, letting the column of the tonnage/volume of sand released blank became a strategy for miners to minimize the taxes they must submit to the BPRD, whereas it was the basis for taxation. Likewise, with duplicating SKAB, where one sand transporting 
vehicle with a certain tonnage should only get one SKAB series when exiting a portal, and then get a new serial number when transporting again. With this duplication, if the vehicle exits five times the mining area with a certain tonnage, the truck driver should have five SKAB serial numbers. But what happened on the field was that there were a lot of trucks passing more than once tax collection portals but each driver only had one SKAB serial number. That showed miners did duplication of non-standardized SKAB.

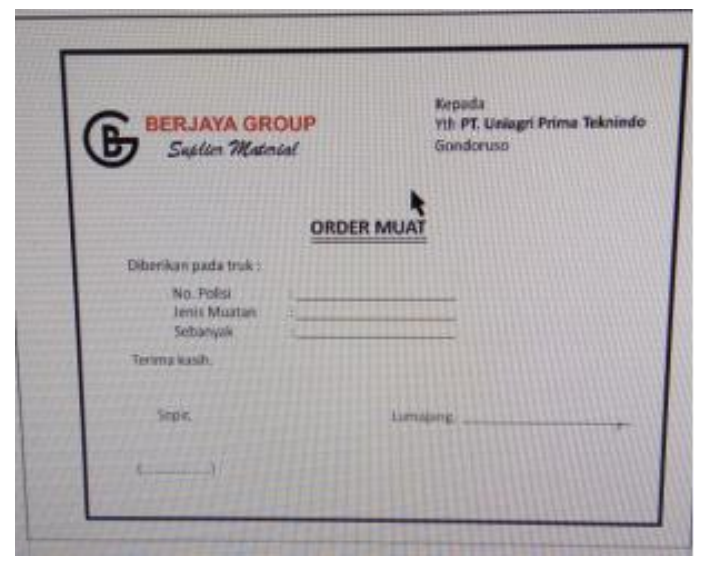

Source: Field survey data (2018)

Figure 3. Non-standardized SKAB

This duplication of SKAB was what the authors believed as the main cause of a substantial sand tax leak where the Taxpayers who were authorized by the BPRD should be able to be responsible for the SKAB. Based on Subandi et al., (2018), regional taxes have a direct relationship with regional income which means that the growth of regional tax revenues is generally in line with the growth of the Regional Original Income of Lumajang but inversely proportional to the level of awareness of taxpayers, especially sand miners, which is contrary to the growth of regional income. Awareness of payment of taxes in general is also contrary to the growth of regional income. This indicates that awareness of paying taxes in Lumajang Regency needs to be improved. That is because the ability of the Lumajang community to pay taxes is quite high.

\section{Conclusion}

The abundance of sand mining in Lumajang Regency is expected to have a positive impact on economic development of Lumajang. But there are polemic problems at the Lumajang community level due to the leakage of public policies that must be immediately corrected by the local government in collaboration with the community and miners in Lumajang Regency.

\section{References}

Aini, N. (2015, October 8). Why Lumajang sand becomes scramble?. Republika. Retrieved from https://nasional.republika.co.id/berita/nasional/umum/nvvpjb382/mengapa-pasirlumajang-jadi-rebutan

Baker, J. L., \& Gadgil, G. U. (Eds.). (2017). East Asia and Pacific Cities: Expanding Opportunities for the Urban Poor. Washington DC: The World Bank.

Benoit, G., \& Comeau, A. (2012). A sustainable future for the Mediterranean: the Blue Plan's environment and development outlook. London: EarthScan.

Boni, A., Garibay, C., \& McCall, M. K. (2015). Sustainable mining, indigenous rights and conservation: conflict and discourse in Wirikuta/Catorce, San Luis Potosi, Mexico. GeoJournal, 80(5), 759-780. 
Candeias, C., Ávila, P., Coelho, P., \& Teixeira, J. P. (2018). Mining activities: health impacts. Reference Module in Earth Systems and Environmental Sciences, 1-21.

Chandrakanth, M. G. (2015). Water resource economics: towards a sustainable use of water for irrigation in India. Springer.

Datt, D. (2016). Inter-governmental political relations in a federation and illegal mining of natural resources. Environmental Economics and Policy Studies, 18(4), 557-576.

Dyan, R. (2018, February 8). Target of PAD from sand increased to Rp.17 Billion. MemoTimur. Retrieved from http://www.memotimurlumajang.id/2018/02/target-paddari-pasir-naik-jadi-rp-17.html

Farahani, H., \& Bayazidi, S. (2018). Modeling the assessment of socio-economical and environmental impacts of sand mining on local communities: A case study of Villages Tatao River Bank in North-western part of Iran. Resources Policy, 55, 87-95.

Inkenbrandt, P., Lund, W., Lowe, M., Knudsen, T., \& Bowman, S. (2014). Investigation of land subsidence and earth fissures in Cedar Valley, Iron County, Utah (Vol. 150). Utah Geological Survey.

Knopp, L. (2012). What the River Carries: Encounters with the Mississippi, Missouri, and Platte. Missouri: University of Missouri Press.

Nordin, R. M., Takim, R., \& Nawawi, A. H. (2013). Behavioural factors of corruption in the construction industry. Procedia-Social and Behavioral Sciences, 105, 64-74.

Ramachandra, T. V., Vinay, S., \& Chandran, M. S. (2018). Quantification of annual sediment deposits for sustainable sand management in Aghanashini river estuary. Journal of environmental management, 206, 1263-1273.

Ramkumar, M., Kumaraswamy, K., \& Mohanraj, R. (Eds.). (2015). Environmental management of river basin ecosystems. Springer.

Taylor, A. N., Cullinan, P., Blanc, P., \& Pickering, A. (2016). Parkes' Occupational Lung Disorders. New York: CRC Press.

Wood, M. C. (2014). Nature's trust: Environmental law for a new ecological age. Cambridge: Cambridge University Press. 